по направлению «Библиотечно-информационная деятельность», проведенного на базе Алтайского государственного института культуры 5 февраля 2020 года. В ходе обсуждения неоднократно акцентировалось внимание участников на проблеме многофункциональности библиотечной профессии, исходя из этого, о необходимости углубленной подготовки обучающихся по многим направлениям, и в том числе коммуникационным технологиям. В муниципальных, вузовских библиотеках в современных реалиях должна быть взаимозаменяемость специалистов. В этих условиях важно, чтобы библиотекари - выпускники вуза могли себя самопрезентовать, обладали навыками позиционирования себя в коллективе. Конфликтологическая грамотность, информационная компетентность, умение работать в условиях многозадачности - это не весь, но ключевой перечень современных требований работодателей к выпускникам вузов.

В целом следует отметить, что развитие конфликтологической грамотности бакалавров следует рассматривать как последовательный и происходящий в определенном временном интервале и социально-психологических условиях образовательной среды процесс, обеспечивающий качественно новый уровень межличностного взаимодействия. Представленная тренинговая модель развития конфликтологической грамотности обучающихся может быть применена при создании специализированных обучающих семинаровтренингов.

\section{Список литературы}

1. Нагайщеев В. B. Конфликтологическая грамотность населения региона // Society and Security Insights. 2018. № 1. C. 93-98.

2. Трофимова Р. А., Растов Ю. Е., Нагайцев $B$. B. Конфликтология. Барнаул, 2006. 127 с.

3. Трофимова Р. А. Конфликтологические загадки в рассказах А. П. Чехова // Социальноинформационные ресурсы библиосоциальной работы. Барнаул, 2011. Вып. 12. С. 8-12.

4. Трофимова Р. А., Растов Ю. Е. Конфликтологическая загадка рассказа А. П. Чехова «Новая дача»// Учёные записки. 2010. № 6: Теория и практика исследования социально-культурной деятельности, художественного образования, информ. ресурсов. С. 171-173.

5. Денисов О. И. Развитие конфликтологической компетентности руководителей : автореф. дис. ... канд. психол. наук: 19.00.13. Москва, 2001. URL: https://www.dissercat.com/content/razvitiekonfliktologicheskoi-kompetentnosti-rukovoditelei (24.10.2020). mila_san@mail.ru

\title{
АЛТАЙСКАЯ КРАЕВАЯ ДЕТСКАЯ БИБЛИОТЕКА ИМЕНИ Н. К. КРУПСКОЙ: 100 ЛЕТ СЛУЖЕНИЯ ДЕТЯМ И КНИГЕ
}

Аннотация. На протяжении века Алтайская краевая детская библиотека им. Н. К. Крупской остается притягательным «третьим» местом для детей и подростков, их родителей и педагогов, детских писателей и иллюстраторов. История библиотеки богата любопытными фактами и событиями, в том числе трогательной перепиской с Н. К. Крупской. Современность библиотеки насыщена интересными проектами и акциями, направленными на продвижение чтения.

Ключевые слова: история библиотеки, дети, продвижение чтения, детские книги, культурнопросветительская деятельность.

Датой основания Алтайской краевой детской библиотеки им. Н. К. Крупской (далее - АКДБ) считается 2 апреля 1920 г. Тогда она была создана как детская библиотека г. Барнаула на базе Зайчанской народно-школьной библиотеки, организованной в апреле 1909 г. Обществом попечения о начальном образовании и носившей имя известно- го просветителя В. К. Штильке.

В июне 1922 г. библиотека стала центральной, она занимала тесное помещение в старом деревянном здании на ул. Интернациональной, 69 (позже 73). В августе на должность заведующей была назначена Анна Савельевна Шуругина.

В Государственном архиве Алтайского края 
Культура в евразийском пространстве: традиции и новащии. № 1 (4) 2020 2.

хранится дневник сотрудницы библиотеки, датированный 1924 г., в котором она подробно рассказывает о проведенных мероприятиях, о реакции детей, насколько интересно или сложно им было воспринимать информацию, причем их она всегда ласково называет «ребятки».

Библиотека стала первой детской не только в Барнауле и на Алтае, но и в Западной Сибири. Именно поэтому ею так заинтересовалась Н. К. Крупская, когда на съезде учителей в Москве беседовала с барнаульской учительницей Яковлевой, работавшей в этой библиотеке. С ней она прислала связку книг. В то время при библиотеке работал актив читателей, объединенных в кружок «Друзья библиотеки», который наравне с сотрудниками участвовал в организации её работы. Члены кружка отправили ответное письмо с благодарностью Надежде Константиновне - так завязалась многолетняя переписка. В своих письмах читатели библиотеки рассказывали Н. К. Крупской о себе и своей жизни, о событиях в библиотеке и в городе.

Стоит отметить, что, несмотря на свою занятость, Надежда Константиновна внимательно читала письма ребят, по возможности старалась им ответить. Когда-то это получалось очень кратко, а иногда подробно, с особой теплотой и заботой. Эти письма дети неоднократно зачитывали вслух, обсуждали и, наверняка, стремились приложить еще больше усилий в своей помощи библиотеке и продвижению чтения.

«Надежда Константиновна! Большое вам спасибо за те книги, которые вы нам послали. Сейчас в библиотеке 4200 книг. При библиотеке есть читальня, в которую ходят ребята и читают книги. Есть кружки, которые собираются в неделю один раз. В литературном кружке двадиать человек, руководит этим кружком Анна Савельевна (одна из библиотекарей). Этот кружок разбирает книги и отвечает на вопросы, которые написаны в тетрадях для записи книг. В художественном кружке состоят пятнадиать человек, руководит кружком Тетя Витя. Кружок этот рисует плакаты, лозунги, выпускает газеты стенные, уже выпустил номеров восемь. Все это идет в пользу украшению читальни. Еще художественный кружок рисует и помогает женотделу. Деревне Коммуна Муравей мы теперь уже послали третий раз плакаты и лозунги и обновляем ихные уголки. Надежда Константиновна, мы все члень кружков при ичентральной детской библиотеке просим вас, чтобы библиотека была в честь вашего имени. Если вы согласны, то напишите ответ на нашу просьбу. Еще забыли вам сказать, что читальня выписывает газеты, журналь: Юные строители, Пионер, Мурзилка, Барабан, Вожатый, Новый Робинзон.
Мы от имени читальни и библиотеки писали вам письмо восемнадцатого апреля двадцать пятого года и мы не знаем, почему вы нам не дали ответа.

Сейчас у нас читальню и библиотеку закрыли по случаю скарлатины. У нас в Барнауле болеют очень много народу. И нам без книг скучно...» (17.12.1925)

«Дорогие ребята! Тов. Сергеева привезла ваше письмо. Большое спасибо за него. Я рада буду, если ваша библиотека будет называться моим именем. Я рада, что вы - друзья библиотеки. Владимир Ильич также был другом библиотеки. Ему хотелось, чтобы в нашей стране было как можно больше библиотек и чтобы они были как можно лучше организованы, обслужсивали как можно больше народа. Ваше письмо, наверное, порадовало бы его. Я очень виновата, что не ответила на ваши письма, была занята.

Рада буду, если вы будете писать о работе вамей библиотеки. Посылаю вам свой портрет, когда была девочкой 8-ми лет.

Может быть, он доставит вам удовольствие.

Желаю успеха в работе и шлю горячий привет» (23.06.1926)

«Надежда Константиновна! Ваше письмо и подарок мы получили. Вы наверное не сможете представить радость и счастье с каким мы получили от вас дорогой подарок, большое илем вам спасибо.

Сообщаем радость: нашу библиотеку расширили, вниз перевели самую библиотеку, а наверху осталась только читальня, есть теперь у нас новые скамейки и столь.

Сейчас напишем о работе. Летом ребята хоть и уезжали в деревни, а в библиотеке было много ребят. Читальня летом была закрыта на один месяи на время отпусков.

Когда мы получили письмо, то считали себя счастливыми...» (1926)

«Надежда Константиновна. Mbl друзья и читатели детской библиотеки. Шлем вам горячий привет...

...Нам передали, что родина вашей мамь Барнаул, что и очень приятно. Нам хочется узнать, где она жила: в самом ли городе или в каком районе? Напишите. Сейчас наша библиотека закрыта для проверки книг, а в читальне мь тоже исправляем и подклеиваем книги. Нас распустили на каникуль и все ребята стали разъезжаться на дачи и в деревни.

Если Вы поедете в отпуск, то приезжайте к нам. 
C нетерпением ждем ответа. Напишите, как у вас готовятся к 10-й годовщине Октября. Приезжайте к нам к годовщуине» (18.07.1927)

«Дорогие ребята!

Получила «привет от детей сибиряков», фотографии Барнаула и ваши письма. За все большое спасибо.

Праздник Октября у нас прошел очень торжественно. Никогда еше не было такого торжества. У нас было много иностранцеев. Они говорили, что никогда не думали, что у нас рабочие и работницы так организовань, и жизнь так налажена. Некоторые прожили в Москве и Ленинграде по 2-3 недели, им понравились наши школьг и наши ребята. Ребята у нас, правда, хорошие»

Ну, всего хорошего. Ещче раз спасибо за присланное» (7.01.1928)

«Надежда Константиновна! Шлем вам горячий привет и желаем вам всего хорошего...

Надежда Константиновна, у нас сейчас большая неприятность, что библиотека закрыта. Причины этого то, что в городе распространена корь и скарлатина. В читальню пока разрешили пускать не более 50 человек в день. Читальню посещают большей частью младшие группы второй и третьей. Они очень любят книжки и рисовать; и ещзё любят громкое чтение, которое бывает два раза в неделю...

...Напишите, читают ли у вас ребята газетьл? Также илем горячий привет Марье Ильиничне. Сегодня ребят мало, потому что мороз $40^{\circ} \ldots »$ (26.01.1928)

«Дорогая Н. К., илём Вам 1-майский привет! С 1 апреля в г. Барнауле введено всеобщее обучение и начался новый учебный год, и поэтому в нашей библиотеке состав кружка изменился. Mbl на Вас, Н. К., обижаемся, потому что мы от вас с прошлого года ни одного письма не получали, так что наш кружок просит вас послать хоть открытку. Bbl в своей книжке «Пионерам о библиотеке» рекомендуете устраивать кружки красных чтецуов. С 10 ноября 1929 2. по 1 мая 1930 г. y нас через кружок красных чтециов прошло 59 человек, они провели 249 читок дома, в отрядах и школах и охватили 1770 человек. Книжки давали читать о сельском хозяйстве, антирелигиозные и о красной армии. Кружки безбожника и эсперанто нынче работали не долго. Наши ребята принимали участие в сборе книг. Из собранных книг в деревню Иню послали 30 книг, а к 1 мая ещуе 50, и послали краски - по их просьбе, и ещзе послали 300 книг в Мамонтовский район в коммуну «Равенство».
Надежда Константиновна, у нас плохо дело идет с пионерским руководством. Горбюро Ю. П. за зиму к нам прикрепляли два отряда 16 и 11, но они ничего не работают, книгой они не интересуются, но по отдельности пионеры читатели из разных отрядов у нас работают хорошо.

Вчера 2 мая читатели ставили отчетную постановку в Д.Р.П. и пропагандировали пионерские газеты и журналь, и если нас снимут с увеличенными книгами, то мы вам пошлем карточку. Ждем письма» (1930)

\section{«Дорогие ребята!}

Получила ваш первомайский привет. Спасибо. Не могла сразу ответить - была очень занята. Сейчас у меня начался отпуск и я его использую, чтобь ответить на письма. Меня очень порадовало, что вы устраивали читки, послали книги в колхоз «Равенство» и в деревню Иню. Это очень хорошо. Не бросайте эту работу, она очень нужная. Еще раз спасибо за письмо» (9.08.1930)

В апреле 1939 г., после ходатайства коллектива Барнаульской детской библиотеки под руководством М. А. Васильевой, Решением Оргкомитета Президиума Верховного Совета РСФСР по Алтайскому краю библиотеке официально присвоено имя Н. К. Крупской.

В годы Великой Отечественной войны библиотека не закрывалась, хотя проблемными были и изношенный фонд, и обветшавшая мебель, и частая смена кадров.

Из отчёта библиотеки за 1944- 45 гг.: «Omсутствие топлива в течение зимы создало тяжёлое положение для работь. Работали при 18-20 градусах ниже нуля, что вызывало частые заболевания работников. Несмотря на неблагоприятные условия, библиотека не прекращала работу. Абонемент был закрыт только 10 дней, читальня 28 дней в феврале месяце, когда были особенно сильные морозы - 50-55 градусов. Работа библиотеки проводилась с 9 до 19 часов ежедневно, кроме вторника. Читальный зал работал с 11 до 18 часов».

В 1945 г. силами детей был создан «Фонд читателя» - более 100 томов самой востребованной приключенческой литературы из личных собраний читателей переданы во временное пользование библиотеке.

Особое внимание в эти годы уделялось культуре поведения, дисциплине в библиотеке: тишина, чистота рук, вежливость.

Несмотря на тесное помещение, библиотека была центром притяжения детей - здесь проводились громкие читки, ставились сценки и «живые газеты», проходили литературные мероприятия в сопровождении аллоскопа, проецирующего на стену картинки, помогающие восприятию информации. 
Культура в евразийском пространстве: традиции и новащчии. № 1 (4) 2020 2.

Самыми яркими из проводимых библиотекой мероприятий для детей становились встречи с интересными людьми: писателями, артистами, художниками, участниками войн. К примеру, на вечер, посвященный 38-й годовщине Октябрьской Революции, были приглашены участники гражданской войны на Алтае - Афанасий Андреевич Полухин и Дарья Афанасьевна Мамонтова, которые рассказали ученикам 5-7 классов о борьбе партизан на Алтае. В 1951 г. при встрече с артистом драмтеатра С. Хлытчиевым детей интересовало, где он учился, давно ли работает артистом, видел ли Сталина, как на сцене стреляют, где ему шили костюм для исполнения роли Сталина (многие были уверены, что его прислали из Кремля). Общаясь с писателями (Л. Квином, В. Сидоровым, И. Злывко, Н. Головиной, М. Юдалевичем и др.), дети зачастую становились первыми слушателями новых произведений и, высказывая свои впечатления о них, очень помогали авторам.

В 1955 г. библиотека получает статус краевой, становится методическим центром по работе с детьми, переезжает в новое помещение по ул. Новой, 21 (ныне - проспект Строителей). Старое оборудование по причине ветхости не перевозили, приобрели новое: 4 прилавка, 6 стендов, 100 стульев, 4 мягких кресла, 3 мягких дивана, 2 ковра, 2 пишущие машинки. В штате уже 17 человек (в 1951 г. всего 6).

Загруженность работников обустройством на новом месте не мешает вдумчивому обслуживанию читателей. Годовые отчеты библиотеки содержат выписки из читательских формуляров, отражающие не только широкий спрос и разносторонние интересы юных читателей, но даже судьбы детей.

Песняк Петя - ученик 7 класса. В детской библиотеке читает с 1953 г. Редко встречается такой глубокий, разносторонний интерес к книге, какой мы видим у Пети. В библиотеку он идет уже с готовыми требованиями и всегда знает, какую книгу надо спросить. Он читает с одинаковым интересом обо всем, но все-таки предпочтение отдает путешествиям. Нет, кажется, в библиотеке книги из географического отдела, которую бы не читал Петя. Он никогда не удовлетворялся одной художественной книгой - ему нужно обязательно дать что-нибудь из научных отделов, особенно из географии. Прочитал он за годы пребывания в библиотеке очень много книг, и количество формуляров в его сумочке очень велико, а записей в них еще больше.... Он хорошо знаком с литературой по технике, по ботанике и по истории. Вообще Петя Песняк является одним из лучших читателей детской краевой библиотеки.
Бобынин Лева. Читает с 15 лет, пришел в библиотеку в 1947 г. Мальчик умственно отстальий. Читал по складам, интересовался такими книгами, как «Мойдодыр» Чуковского, русские сказки и пр. Через продолжительное время Лева прочитал уже много книг русских классиков и советских писателей, он интересуется книгами, понимает их и может пересказывать прочитанное. А так как в школе он лишен возможности учиться, то все знания, которые имеет, почерпнуты только в библиотеке. С ним работали индивидуально, обслуживали его без очереди и Лева полюбил библиотеку, полюбил книги и до сих пор состоит читателем детской библиотеки.

Лепихов Евгений. Пришел в детскую библиотеку в 1933 г., ему было 9 лет. Отия в семье не было, мать, работавшая в швейной мастерской и обремененная большой семьей, не сумела воспитать мальчика. В силу этого в библиотеку он пришел разнузданным, грубым, не желаюшим подчиняться порядкам библиотеки, но в нем была одна светлая черта - это любовь к книге. Библиотека скоро поняла эту любовь и решила перевоспитать его.

Мальчик очень увлекался приключенческой литературой, интересовался также детективной книгой - ничего другого читать не желал, вел себя очень плохо и совершенно не подчинялся дисииплине. Много усилий и труда пришлось приложить, чтобь заставить его читать книги и по технике и по географии, заинтересовать его историей нашей Родины.

Отдав дань Ж. Верну, Ф. Куперу, Д. Свирину, он перешел к Арсеньеву, Горькому и др. Стал читать книги Ильина М., Житкова Б.

Прошло много лет, и Лепихов стал активнейшим читателем детской библиотеки. Он познакомился с классической литературой, научился владеть собой, научился прислушиваться к советам библиотекаря, научился сам разбираться с книгами.

Началась Отечественная война 1941 г. Женя Лепихов одним из первых был взят на фронт и прошел весь большой путь до самого Берлина. Проявил себя мужественным отважным бойцом за Родину и вернулся с большими боевыми отличиями.

И снова Женя пришел в детскую библиотеку и попросил восстановить его абонемент, заявив, что ни в какую другую библиотеку он не пойдет, так как у него есть «своя родная библиотека». Он стал работать на вагоноремонтном заводе слесарем и одновременно учился в школе взросльх, так как среднее образование до войны закончено не было. Трудился упорно и настойчиво. Библиотека всемерно помогала ему учиться, снабжая его 
учебниками, художественной классической и современной литературой. Приходилось доставать ему книги и из других библиотек. В данное время Женя Лепихов окончил институт инженеров железнодорожного транспорта в Новосибирске. Он член КПСС. Библиотека наблюдала его жизненный путь, от грубого почти беспризорного мальчика до инженера. И по его собственным словам библиотека, «его родная библиотека» помогла ему стать советским человеком в полном смысле этого слова [1].

С июня 1959 г. библиотека открыла доступ к фондам абонемента, благодаря чему возрос интерес к отраслевой литературе. С системой открытого доступа читателей знакомили плакаты, коллективные и индивидуальные беседы - у стеллажей помогали дежурить члены кружка «Друзья библиотеки».

Одним из важных направлений работы являлась профориентация школьников - проводилось анкетирование, оформлялись книжные выставки о людях труда, организовывались диспуты, с детьми встречались с представители разных профессий: учитель, врач, геолог, следователь, военный, астроном, парикмахер, механик, кулинар, слесарь. Активисты библиотеки пообщались со старейшим библиотекарем города, организатором первого кружка «Друзья библиотеки». Встреча проходила в 1965 г. в читальном зале и была отснята студией телевидения. Мария Александровна рассказала об активистах 1930-х гг., о том, чем они занимались, как помогали в пропаганде литературы среди учащихся, о самых больших материальных трудностях, которые испытывали библиотеки 1920-30 гг., сравнила оформление детских книг, рост книжных фондов за годы советской власти.

В дни Недели детской книги в 1963 г. была организована встреча с первой пионеркой Барнаула Т. С. Майоровой. Она рассказала ребятам о своей жизни, как была в Москве на первом съезде пионеров, о трудном времени, в которое они жили, но, несмотря на это, делали большие дела: учили неграмотных, боролись с беспризорностью, собирали металлолом, когда стране был нужен металл.

В честь 45-летия освобождения Алтая от колчаковщины библиотека организовала встречу со старейшими партизанами Алтая Овсюковым и Оборшевым. В гости к ребятам пришел старый коммунар И. В. Репин, который не раз видел и слышал В.И. Ленина, несколько лет работал с Ф. Э. Дзержинским.

Встречались дети и с бывшим читателем и активистом библиотеки, участником Великой Отечественной войны К. С. Владимирским. О его героизме в годы войны писал Д. Медведев в книге «Сильные духом». Константин Сергеевич рассказал, как сражался в партизанском отряде прослав- ленного командира Медведева, о побеге из немецкого плена, прочел ряд писем из своей переписки с Медведевым.

К полувековому юбилею библиотека была заново оборудована - приобретены новые читательские столы и стулья, шкафы и стеллажи. По радио, телевидению и в газетах шла широкая информация о работе библиотеки, сотрудники выступали в школах перед учащимися и родителями с беседами об истории библиотеки. 2 апреля читателей обслуживали и консультировали у книжных полок читатели-активисты, а пионеры приходили поздравлять коллектив.

В целях эффективного руководства чтением в 1970-е гг. продолжается изучение читаемости: в читательском формуляре введены новые графы, за каждым библиотекарем закреплены группы читателей, проводится анкетирование. Ведутся наблюдения за характером чтения, развитием интересов, самостоятельной работой над книгой.

В 1973 г. проведена краевая радиовикторина «Готовься стать защитником Родины», нацеленная на воспитание у подростка чувства патриотизма, уважения к прошлому. В месячник обороны в читальных залах состоялись встречи с командующими краевой игрой «Зарница» генерал-майором М. Т. Карначёвым и участником 56-й гвардейской дивизии И. Г. Колмаковым, который рассказал о жизни и подвиге А. Матросова. Из библиотек и школ края приходили письма, альбомы, поделки читателей - участников радиовикторины. И хотя она была рассчитана на учащихся 6-8 классов, ответы присылали и ребята из 4-5 классов. Всего поступило около 400 работ. В жюри были приглашены работники крайкома ВЛКСМ, командующий игрой Зарница, журналист газеты «Молодежь Алтая» и библиотекари. В итоге 5 участников радиовикторины награждены путевками во Всероссийский пионерлагерь «Орленок», 26 - грамотами, дипломами краевого совета пионерской организации и книгами. Такой формат работы высоко оценили и участники, родители, и библиотекари. В 1986 г. проведена краевая радиоигра «Пионерии 65» и телеконкурс «Мы живем на Алтае». В 1987 г. совместно с краевым дворцом пионеров - телеконкурс «Хроника пионерских дел».

В 1980-е гг. дважды в месяц работает клуб любителей фантастики «Контакт», члены клуба (некоторые впоследствии сами стали писателями) помогают пропагандировать научно-фантастическую литературу среди сверстников, принимают активное участие в проведении занятий в форме обсуждений и КВН [1].

В канун 1982 г. на здании краевой детской библиотеки открыта мемориальная доска, изготовленная на Мытищенском заводе художественного литья, с 
Культура в евразийском пространстве: традиции и новащчии. № 1 (4) 2020 2.

барельефом Н. К. Крупской. Слева от барельефа слова Надежды Константиновны: «Я рада буду, если ваша библиотека будет называться моим именем».

Алтайская краевая детская библиотека им. Н. К. Крупской сегодня - это крупнейшее в крае хранилище произведений для детей, их родителей и руководителей детского чтения; общедоступный информационный центр, осуществляющий культурно-просветительскую и досуговую деятельность, направленную на развитие детей всех возрастов; научно-методический центр для муниципальных библиотек, обслуживающих детей. В Музее истории библиотеки хранятся копии писем участников кружка «Друзья библиотеки» Н. К. Крупской, а также фотографии, благодарственные письма и грамоты, книги с автографами.

Сейчас в библиотеке организована оптимальная пространственная структура для маленьких читателей: небольшие уютные залы приспособлены к интересам и потребностям детей, выделены зоны с учётом увлечений и возрастных особенностей детей, созданы комфортные условия для работы с книгой. В структуре библиотеки 5 отделов: обслуживания, формирования и хранения фондов, методический, библиографический, автоматизации и издательской деятельности.

Все экскурсии по библиотеке начинаются со знакомства с Музеем детских писателей Алтая, открытым в 2011 г. благодаря гранту Губернатора Алтайского края в сфере культуры. Каждый раздел музея посвящён уроженцу Алтайского края, внёсшему весомый вклад в детскую литературу: Василию Нечунаеву, Геннадию Целищеву, Валентине Новичихиной, Анне Никольской.

Фонд библиотеки в настоящее время насчитывает более 135 тыс. единиц хранения на различных носителях. С целью ознакомления с печатными новинками юных читателей, проживающих в удалённых от краевого центра населённых пунктах, организуются передвижные «кольцевые» выставки литературы из фондов АКДБ, путешествующие по районам края.

В библиотеке 42 автоматизированных рабочих места, 15 из них - для пользователей с открытым доступом к ресурсам сети Интернет, в том числе Национальной электронной детской библиотеки. В 2018 г. в библиотеке появился детский учебно-игровой терминал «Игрёнок», содержащий разнообразные учебно-познавательные игры для детей от 3 до 12 лет.

В ноябре 2011 г. создан сайт библиотеки [2] со средней посещаемостью более 80 тысяч в год, который освещает деятельность библиотеки, содержит обширную информацию по краеведению, творчеству детских писателей; новости библиотек края, а также предоставляет возможность доступа к электронному каталогу библиотеки. Новости библиотеки и интересная информация размещаются и в соцсетях: «Одноклассники» (группы «Библиотекарь - это звучит!» и «Алтай - пространство исследования») и «ВКонтакте» (группа «Алтайская краевая детская библиотека им. Н.К. Крупской».

Библиотека ведёт масштабную культурнопросветительскую работу - ежегодно проводятся более 600 массовых мероприятий для детей и подростков по актуальным направлениям краеведения, профориентации, духовно-нравственного, историко-патриотического, эстетического, семейного воспитания, здоровьесбережения, экологического, правового просвещения, профилактики правонарушений. АКДБ не только активно участвует во всероссийских и международных сетевых акциях, но и организует акции для своих читателей, к примеру: «Книжный мешок», «Охотники за автографами», «Поменяй учебник», а также краевые сетевые: День детской краеведческой книги, патриотический флешмоб «Связь поколений не прервётся!», Единый библиотечный день, квест «Алтай - пространство исследования» $[3,4,5]$.

В 2012 г. в числе первых в крае АКДБ присоединилась к акции «Библионочь» Каждый раз увлекательные путешествия по просторам библиотеки, ежегодно отражающие как различную официально заявленную тематику, так и местные нюансы, оставляют множество ярких и приятных эмоций и у детей, и у родителей, и у коллектива организаторов, и у всех, кто оказывает библиотеке техническую, организационную и спонсорскую поддержку. Популярность акции не угасает, количество посетителей с каждым годом не уменьшается - приходят как постоянные читатели, так и те, кто впервые переступил порог библиотеки и увидел её потенциал. Разнообразие интерактивных площадок, ориентированных и на совсем малышей, и на младших школьников, и на подростков, привлекает их внимание на протяжении всего вечера. С самой первой Библионочи оказалась удачной идея Библиомагазина, ставшая неотъемлемой частью всех последующих. Основной его принцип в том, что ребёнок выбирает себе подарок сам, проявляя активность в викторинах и конкурсах, используя свои знания и начитанность [6].

Библионочь-2014 была удачно использована для реализации гранта Губернатора Алтайского края в сфере культуры по проекту «Детская книга - формат международного сотрудничества». Уникальность проекта заключалась в возможности расширения границ культурного сотрудничества между Россией и Казахстаном. Дети Алтайского края увидели музейные экспонаты Детского литературно-художественного музея А. М. Волкова, 
узнали об исторической связи писателя с Алтаем, ближе познакомились с его литературным творчеством. В ходе проекта организована литературнохудожественная выставка по творчеству А. М. Волкова, которую предоставил общественный фонд «Изумрудный город» из УстьКаменогорска.

Главная идея историко-литературной квестигры «Алтай - пространство исследования», инициированной в 2010 г., - привлечение к чтению как можно большего числа детей и подростков с помощью интерактивных информационных технологий, организация интеллектуального общения школьников. Каждый сезон игры посвящён знаковым календарным событиям края, тематика игр определялась ключевыми событиями его культурной жизни. Результатом участия в игре становятся интересные проекты, популяризирующие творчество алтайских писателей в сетевом пространстве, видеоролики о достопримечательностях села или района, веб-страницы на сайтах школ, посвященные прославившим Алтай землякам - своеобразный банк краеведческой информации, служащий подспорьем в получении знаний об Алтайском крае.

Ежегодно с 2013 г. АКДБ объявляет краевую сетевую акцию «День детской краеведческой книги на Алтае». Присоединившиеся к акции муниципальные библиотеки и другие учреждения проводят разнообразные мероприятия по продвижению краеведческой литературы, затем присылают отчеты с фотографиями на сайт АКДБ. Краевая сетевая акция «День детской краеведческой книги на Алтае» стала настолько популярной, что в ней принимают участие не только детские библиотеки, но и поселковые, и школьные, а также музеи и дошкольные учреждения. Количество участников с 22 в 2013 г. выросло к 2019 г. до 156 учреждений края, охвативших 4,4 тыс. детей, прочитавших более 9 тыс. книг алтайских писателей $[7,8]$.

С 2016 г. в канун празднования Дня Победы проводится краевой патриотический флешмоб «Связь поколений не прервётся!», имеющий целью привитие детям и подросткам чувства гордости за свой народ, благодарности защитникам Отечества, привлечение к чтению произведений местных авторов о Великой Отечественной войне. Среди обязательных условий проведения флешмоба: мастер-класс по изготовлению символа войны - фронтового треугольника, где дети пишут слова благодарности защитникам Отечества либо пожелания мира; торжественное шествие по маршруту от библиотеки до местного памятника героям Великой Отечественной войны (солдатские треугольники с пожеланиями мира раздаются про- хожим во время шествия, со словами благодарности - возлагаются к памятнику); минута молчания; чтение хором тематического стихотворения. В 2019 г. в акции приняли участие 95 библиотек из 43 территорий Алтайского края, привлекших 4 тысячи детей и подростков.

Уже несколько лет АКДБ является площадкой краевого фестиваля книги «Издано на Алтае», Всероссийского фестиваля науки, Всероссийской акции «Большой этнографический диктант», Всероссийской олимпиады «Символы России». Проводятся совместные конкурсы с библиотеками других регионов (Республик Казахстан и Бурятия, Новосибирска, Омска, Томска и др.).

С 2012 г. сотрудник библиотеки В. Е. Тихонов, член Союза писателей России, представляет читателям свой авторский проект - литературнопросветительскую программу «Испытание временем», в которой более 20 тематических встреч, посвящённых жизни и творчеству классиков и современников отечественной литературы: А. С. Пушкина, С. А. Есенина, В. П. Астафьева, Н. М. Рубцова, В. Б. Свинцова, И. М. Пантюхова, В. А. Новичихиной, С. С. Яненко, Б. В. Капустина и др.; поющих поэтов - В. С. Высоцкого, Н. А. Шипилова, В. Г. Верстакова, А. А. Карпова, А. В. Власова и др. Мероприятия программы проходят и в других учреждениях: школах Барнаула, Центре временного содержания несовершеннолетних правонарушителей г. Барнаула при ГУВД Алтайского края, а также в райцентрах и городах края.

С 2014 г. реализуется совместный проект краевого радио (Вести22.ТВ) и АКДБ им. Н. К. Крупской «Мама читает книжку», выпуски которого можно услышать на радиостанциях «Маяк» и «Радио России». Это детская радиопрограмма для родителей и детей дошкольного и младшего школьного возраста, где известные мамы города читают своим детям любимые книги, выбранные вместе с краевой детской библиотекой, соведущаябиблиотекарь знакомит радиослушателей с новинками литературы для детей, имеющимися в фонде библиотеки.

Большое значение АКДБ придаёт издательской деятельности: выпускаются информационноаналитические, методические, библиографические материалы в помощь детям, родителям, руководителям детского чтения, библиотекарям, работающим с детьми. Ключевое её направление - краеведение, в частности - литературное краеведение, знакомство детей с творчеством писателей нашего уникального края. Интересны формы издательской продукции: пособия-игрушки, пособия-картотеки, фактографы и др. 
С 2011 г. с целью продвижения лучших произведений алтайских авторов, пишущих для детей, библиотека реализует издательский проект «Писатели Алтайского края - детям». Все выпущенные в рамках проекта книги на безвозмездной основе поступают в детские библиотеки, чтобы творчество земляков стало доступнее для ребят из самых отдаленных уголков Алтайского края. В дополнение к изданным книгам готовятся небольшие видеоролики с обращением писателя к своим маленьким читателям. Кроме того, что книги алтайских писателей пополняют краеведческие фонды детских библиотек, они становятся основой проведения краевой сетевой акции «День детской краеведческой книги на Алтае».

В 2014 г. издательский проект был представлен в Новосибирске на 8-м Фестивале детских библиотек Сибири, где в одной из номинаций стал победителем как уникальный, многогранный, перспективный и не имеющий аналогов. В 2018 г. за реализацию издательского проекта творческий коллектив сотрудников АКДБ стал лауреатом премии Алтайского края в области литературы, искусства, архитектуры и народного творчества в номинации «Просветительская деятельность».

Гордостью издательской деятельности библиотеки по праву считается книга «Далёкие зимние вечера» В. М. Шукшина, подготовленная к его 85летию при поддержке Губернатора Алтайского края А. Б. Карлина и адресованная детям среднего и старшего школьного возраста. Каждый рассказ предваряет своеобразный отзыв - письмо или стихотворение ребёнка, участника читательской конференции «Из страны детства В. М. Шукшина», а иллюстрациями к рассказам стали рисунки детей из городов и районов Алтайского края. 4 ноября 2014 г. во время вечера памяти знаменитого земляка в столичном Театре наций вдова писателя Лидия Федосеева-Шукшина подарила эту книгу Президенту России Владимиру Путину. Кроме того, эта книга стала победителем в номинации «Лучшая книга для детей» конкурса «Лучшая книга Алтая-2014».

Благодаря грантовой поддержке проекта АКДБ «Детские писатели в гостях у поЧитателей» в 2018 г. алтайские писатели, участники издательского проекта библиотеки, провели творческие встречи с читателями детских библиотек края.

В начале 2018 г. к специалистам АКДБ им. Н.К. Крупской за помощью в подготовке очередного номера обратилась редакция «Роман-газеты», в результате чего из печати вышел специальный номер российского журнала «Детская Романгазета», посвящённый Алтайскому краю. В спецвыпуск, адресованный читателям среднего школьного возраста, вошли произведения алтайских авторов для детей, познавательные материа- лы, а также страничка детского творчества с рисунками и стихами талантливых ребят. Традиционно структура журнала не предполагает включение стихотворений, но для спецвыпуска редакция сделала исключение и опубликовала стихи поэтов Алтайского края.

Методическая деятельность АКДБ направлена не только на сбор и анализ информационностатистических материалов курируемых библиотек, социологические исследования, но и на непрерывное профессиональное самообразование и обучение коллег $[8,9,10,11,12]$. Ежегодно проводятся краевые семинары-совещания руководителей и специалистов библиотек края, обслуживающих детей; тематические зональные семинары; Дни АКДБ; действует Школа детского библиотекаря. С 2010 г. ежегодно выпускается научно-методический сборник «Вопросы теории и практики библиотечного обслуживания детей и подростков в Алтайском крае». За эти годы на страницах сборника о своих достижениях рассказали многие детские библиотеки Алтайского края, а в рубрике «Опыт коллег» своими наработками поделились специалисты Хакасии, Бурятии, Республики Алтай, Казахстана, Липецка, Белгорода, Кемерово, Красноярска, Новосибирска, Омска, Томска, Челябинска, Самары и др. [3].

Важным фактором качественной работы библиотек является её кадровый потенциал: от профессиональных и личных качеств библиотекаря зависит оптимальное функционирование библиотеки. Большой вклад в развитие библиотеки внесли её руководители: А. С. Шуругина, М. А. Васильева, Г. Ф. Самсонова, М. А. Казанцева, 3. И. Шахова, Р. В. Балыкова, О. А. Маренко, Т. Н. Кушвид. Многие специалисты АКДБ, способные увлечь ребёнка, воспитать талантливого читателя, получали заслуженные награды и неоднократно становились лауреатами и победителями ежегодного краевого конкурса профессионального мастерства «Лучший работник культуры».

Несмотря на постоянно меняющуюся реальность, на протяжении века библиотека остаётся притягательным «третьим» местом для детей и подростков. Здесь они не только соприкасаются с историей и культурой через книгу, но и имеют возможность пообщаться непосредственно с её автором - детским писателем. Сотрудничество библиотеки с детскими писателями даёт вполне ощутимые результаты, все акции и проекты, направленные на продвижение чтения, получают благодарный отклик основной целевой аудитории - читателей-детей. Коллектив АКДБ им. Н. К. Крупской понимает, что необходимо постоянно искать новые подходы, удивлять и увлекать детей - самую восприимчивую возрастную категорию посетителей. 


\section{Список литературы и источников}

1.Государственный архив Алтайского края. Ф. P1198.

2. Алтайская краевая детская библиотека им. Н. К. Крупской : [сайт]. [Барнаул, -2020]. URL: http://www.akdb22.ru/ (22.11.2020).

3. Ежегодный отчёт о работе краевого государственного казённого учреждения «Алтайская краевая детская библиотека им. Н. К. Крупской» за 2010 г. Барнаул, 2009.

4. Ежегодный отчёт о работе краевого государственного казённого учреждения «Алтайская краевая детская библиотека им. Н. К. Крупской» за 2011 г. Барнаул, 2010.

5. Ежегодный отчёт о работе краевого государственного казённого учреждения «Алтайская краевая детская библиотека им. Н. К. Крупской» за 2012 г. Барнаул, 2011.

6. Ежегодный отчёт о работе краевого государственного казённого учреждения «Алтайская краевая детская библиотека им. Н. К. Крупской» за 2013 г. Барнаул, 2012.

7. Ежегодный отчёт о работе краевого госу- дарственного казённого учреждения «Алтайская краевая детская библиотека им. Н. К. Крупской» за 2014 г. Барнаул, 2013.

8. Ежегодный отчёт о работе краевого государственного казённого учреждения «Алтайская краевая детская библиотека им. Н. К. Крупской» за 2015 г. Барнаул, 2014.

9. Ежегодный отчёт о работе краевого государственного казённого учреждения «Алтайская краевая детская библиотека им. Н. К. Крупской» за 2016 г. Барнаул, 2015.

10. Ежегодный отчёт о работе краевого государственного казённого учреждения «Алтайская краевая детская библиотека им. Н. К. Крупской» за 2017 г. Барнаул, 20016

11. Ежегодный отчёт о работе краевого государственного казённого учреждения «Алтайская краевая детская библиотека им. Н. К. Крупской» за 2018 г. БарнаулБ, 2017.

12. Ежегодный отчёт о работе краевого государственного казённого учреждения «Алтайская краевая детская библиотека им. Н. К. Крупской» за 2019 г. Барнаул, 2018.

\section{РАСШИРЕНИЕ СПЕКТРА АДАПТИВНЫХ УСЛУГ ДЛЯ ПОЛЬЗОВАТЕЛЕЙ С ОГРАНИЧЕННЫМИ ВОЗМОЖНОСТЯМИ ЗДОРОВЬЯ В АЛТАЙСКОЙ КРАЕВОЙ СПЕЦИАЛЬНОЙ БИБЛИОТЕКЕ ДЛЯ НЕЗРЯЧИХ И СЛАБОВИДЯЩИХ}

Аннотация. В статье приводится опыт работы Алтайской краевой специальной библиотеки для незрячих и слабовидящих с людьми с ограниченными возможностями здоровья. Охарактеризованы современные формы и методы предоставления библиотечно-информационных услуг, раскрываются качественно новые возможности библиотечно-информационного обслуживания пользователей с ограниченными возможностями здоровья, обусловленные распространением цифровых технологий.

Ключевые слова: люди с ограниченными возможностями здоровья, маломобильнье пользователи, слепье и слабовидящие, специиальная библиотека, циифровизация, библиотечно-информационные технологии.

Сегодня трудно представить библиотеку, которая занимается только выдачей книг. Глобализация, информатизация, развитие современных адаптивных технологий, в том числе для инвалидов и маломобильных пользователей, требуют от библиотечных специалистов внедрения инноваций в формы и методы работы, переустройства внутреннего пространства учреждений, постоянного повышения квалификации, внедрения новых профессиональных стандартов.

Созданная в 1953 году Алтайская краевая специальная библиотека для незрячих и слабовидящих первоначально располагалась на площади 18 кв. м. и оказывала библиотечные услуги незрячим города Барнаула. Ее фонды состояли из изданий рельефно-точечного шрифта. С увеличением 